\section{Metamorphic evolution of carbonate-hosted microbial biosignatures}

\author{
C.R. Cousins ${ }^{1 *}$, S. Mikhail ${ }^{1,2}$, F. Foucher ${ }^{3}$, A. Steele ${ }^{2}$, F. Westall ${ }^{3}$
}

Abstract

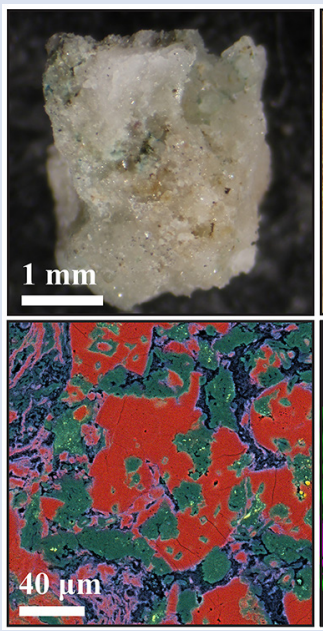

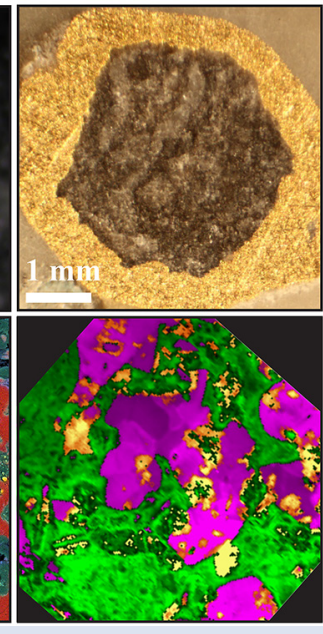

Microbial biosignature assemblages captured within mineral substrates experience extreme pressures $(\mathrm{P})$ and temperatures $(\mathrm{T})$ during rock burial and metamorphism. We subjected natural microbial biofilms hosted within thermal spring carbonate to six high pressure, high temperature (HPHT) conditions spanning 500 and $800 \mathrm{MPa}$ and 200 to $550{ }^{\circ} \mathrm{C}$, to investigate the initial petrographic transformation of organic and inorganic phases. We find biogenic and amorphous silica mineralises increasingly mature organic matter $(\mathrm{OM})$ as temperature and pressure increase, with $\mathrm{OM}$ expelled from recrystallised calcite at the highest HPHT, captured within a quartz phase. Sulfur globules associated with microbial filaments persist across all HPHT conditions in association with microbially-derived kerogen. These data demonstrate how microbial material captured within chemically-precipitated sediments petrographically evolves in high grade rocks during their first stages of transformation.

Received 12 August 2019 | Accepted 6 December 2019 | Published 16 January 2020

\section{Introduction}

Our knowledge of microbiological evolution is informed by organic, morphological, and geochemical biosignatures preserved within a rock record that is destroyed or modified over geological time (Westall, 2008). Chemically-precipitated sediments, particularly carbonate and silica, host microfossils spanning much of Earth history, including in association with early evidence for microbial life on Earth (Moreau and Sharp, 2004; Westall, 2008; Wacey et al., 2011; Djokic et al., 2017). The petrographic relationships between microbially-derived kerogen and the inorganic matrix are important in establishing microfossil biogenicity (Brasier et al., 2005; Wacey et al., 2011; Foucher and Westall, 2013), in addition to understanding broader interations of microbe-mineral systems back into the early Archean (Westall et al., 2015).

Significant experimental effort has furthered our understanding of microbial biomineralisation (Westall et al. 1995; Orange et al., 2012, 2014; Li et al., 2013a and references therein; Gaboyer et al., 2017). High pressure, high temperature (HPHT) experiments are now shedding light on microfossil taphonomy during geological sequestration, with a focus on thermal degradation of biogenic minerals (Li et al., 2013b) and biomineralised cells (Li et al., 2014). Experiments have demonstrated the persistence of microbiological structures such as iron oxide organominerals up to $250^{\circ} \mathrm{C}$ and $140 \mathrm{MPa}$ (Picard et al., 2015a), and the preservation of lipids and polysaccharides within Fe-encrusted microbial cells at the same PT conditions (Picard et al., 2015b). Recently, Alleon et al. (2016) showed that microbial entombment within silica limited the degradation of molecular biosignatures exposed to $25 \mathrm{MPa}$ and $250{ }^{\circ} \mathrm{C}$ for 100 days.

As improving analytical techniques expand biosignature studies into increasingly metamorphosed terrains (Bernard et al., 2007, 2010; Galvez et al., 2012; Papineau et al., 2019), there is a need to understand the influence of higher PT regimes ( $\mathrm{Li}$ et al., 2013a). We present an experimental investigation into the effects of HPHT on carbonate-hosted microbial biofilms from a natural thermal spring environment. We trace the first stages of petrographic evolution of geochemical and morphological sample components in response to 500 and $800 \mathrm{MPa}$ and temperatures spanning 200 to $550{ }^{\circ} \mathrm{C}$, significantly expanding the PT space previously investigated (Fig. 1a).

\footnotetext{
1. School of Earth and Environmental Sciences, University of St. Andrews, Irvine Building, North Street, St. Andrews, Fife, UK

2. Geophysical Laboratory, Carnegie Institute of Washington, Broad Branch Road, Washington D.C., USA

3. CNRS, Centre de Biophysique Moléculaire, UPR 4301, Rue Charles Sadron, CS80054, 45071 Orléans Cedex 2, France

Corresponding author (email: crc9@st-andrews.ac.uk)
} 


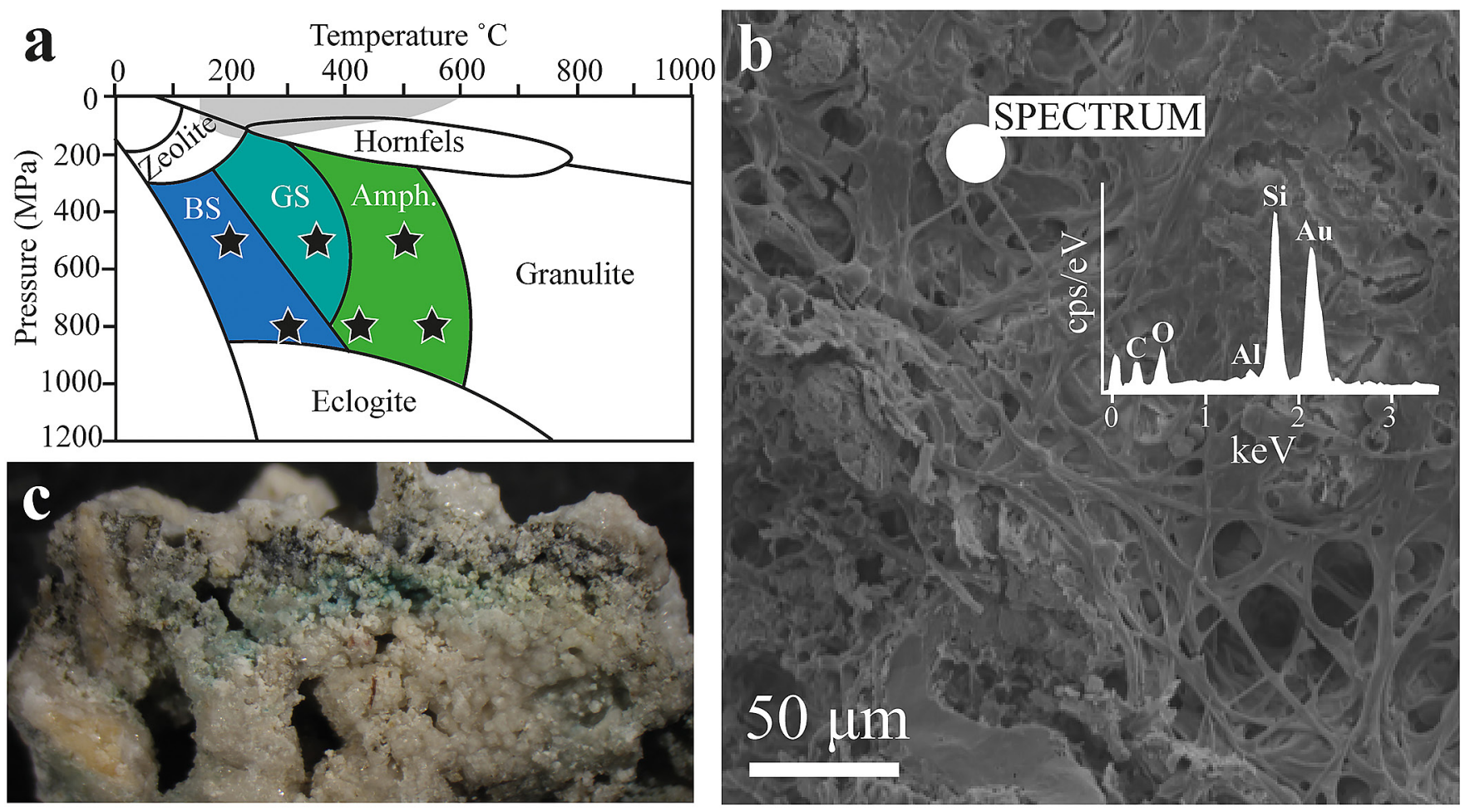

Figure 1 Starting material for experiments showing (a) Six high pressure, high temperature (HPHT) experimental conditions investigated and their corresponding metamorphic grades spanning lower and upper blueschist (BS), greenschist (GS) and amphibolite (Amph.). Grey depicts HPHT conditions investigated previously (Schiffbauer et al., 2012; Li et al., 2013b, 2014; Picard et al., 2015a,b; Alleon et al., 2016, 2017; Miot et al., 2017). (b) Si-rich microbial filamentous material and coccoidal cell structures are observed under SEM in the the starting material, shown in (c) by a view $\sim 1 \mathrm{~cm}$ across; forming Si-rich biofilms around calcite grains (Fig. S-1a,b).

\section{Sample Material}

Porous carbonate precipitates containing green, orange, and grey chasmolithic microbial communities (Fig. 1c) were collected from a $\mathrm{CO}_{2}$ thermal spring (Jotun Spring; Banks et al., 1998) in Spitzbergen, Svalbard, during the Arctic Mars Analog Svalbard Expeditions from 2006-2011 (Starke et al., 2013). An air dried sample was subsampled into multiple 2 $\mathrm{mm}^{3}$ fragments for six HPHT experiments. Four additional fragments of this starting material were subjected to the same preparation and analytical techniques. Methods are described in the Supplementary Information.

\section{Results}

Visible light microscopy of polished HPHT samples reveal dark carbonised organic matter (OM) forming a compositional fabric within the calcite matrix, absent in the starting material (Fig. S-1a,c,d). Secondary electron imaging of a duplicate, acid etched $500 \mathrm{MPa}, 350{ }^{\circ} \mathrm{C}$ sample shows mineralised biomass maintains its intact extracellular filamentous structure (Figs. $1 \mathrm{~b}$ and S-1e) and coccoidal cell morphologies (Fig. S-1f). Intact diatom frustules are preserved at the lower PT conditions (500 $\mathrm{MPa}, 200{ }^{\circ} \mathrm{C}$ and $\left.500 \mathrm{MPa}, 350{ }^{\circ} \mathrm{C}\right)$, becoming structurally disintegrated in the higher $\mathrm{PT}$ experiments $\left(500 \mathrm{MPa}, 500^{\circ} \mathrm{C}\right.$; $800 \mathrm{MPa}, 300{ }^{\circ} \mathrm{C}$ and $800 \mathrm{MPa}, 425^{\circ} \mathrm{C}$; Fig. S-1g,h).

Raman spectra of experimental sample surfaces exhibit peaks for carbonate $\left(1100 \mathrm{~cm}^{-1}\right)$, and D1 $\left(1360 \mathrm{~cm}^{-1}\right)$ and G $\left(1610 \mathrm{~cm}^{-1}\right)$ carbon bands (Fig. 2; Pimenta et al., 2007). An additional quartz band at $465 \mathrm{~cm}^{-1}$ is observed for the three highest temperature samples $\left(425,500\right.$, and $550{ }^{\circ} \mathrm{C}$ ), irrespective of pressure. Secondary electron imaging shows OM transitioning from amorphous biogenic material with cellular structures in the starting material to increasingly crystalline structures as
PT increases (Fig. 2). This is reflected in the changing carbon G-band centre and width, whereby temperatures of $350^{\circ} \mathrm{C}$ and above produce a sharpened (more crystalline) G-band, and the increase in temperature from 200 to $550{ }^{\circ} \mathrm{C}$ also produces a peak centre shift to longer wavenumbers (Fig. S-2). Across all HPHT conditions OM maintains its original petrographic texture, either within a biofilm structure (Fig. 1c), or bound within diatom frustules (Fig. 1).

Raman spectroscopy and SEM+EDS elemental mapping of experimental sample surfaces show kerogenous material (D1 and G Raman bands) remains spatially-concurrent with the siliceous phase (Fig. 3). At the lowest PT condition (500 $\mathrm{MPa}, 200^{\circ} \mathrm{C}$ ), petrographic textures are largely indistinguishable from those in the starting material. At $800 \mathrm{MPa}, 425^{\circ} \mathrm{C}$ (Fig. 3d) these phases form compositional fabrics, where the organic-rich phase exists within silicified or quartz-rich fabrics, which also have elevated Fe (Fig. 4h,i). With increasing PT, the silica-organic phase becomes partitioned from the recrystallising calcite, eventually forming discrete petrographic end members at $800 \mathrm{MPa}$ and $550{ }^{\circ} \mathrm{C}$, whereby kerogen either forms an organic carbonaceous film around quartz crystals (Fig. 3e) or is captured within the quartz itself (Fig. 3f). Water degassing is observed in the carbonate matrix for samples treated at $500 \mathrm{MPa}, 350{ }^{\circ} \mathrm{C} ; 500 \mathrm{MPa}, 500{ }^{\circ} \mathrm{C}$ and $800 \mathrm{MPa}$, $425^{\circ} \mathrm{C}$ (Fig. S-4b,c,e), and extensive fracturing (Fig. S-4b,c,d) is observed at $500 \mathrm{MPa}\left(350{ }^{\circ} \mathrm{C}\right.$ and $\left.500{ }^{\circ} \mathrm{C}\right)$ and $800 \mathrm{MPa}$ $\left(300{ }^{\circ} \mathrm{C}\right)$.

Finally, discrete clusters of sulfur globules $1-3 \mu \mathrm{m}$ in size are observed within the starting material (Fig. 4a,b). These globules persist through all thermal conditions at $800 \mathrm{MPa}$, and at $500 \mathrm{MPa}, 500{ }^{\circ} \mathrm{C}$, remaining petrographically associated with the siliceous kerogen-bearing phase (Fig. 4a-g). At the highest PT condition $\left(800 \mathrm{MPa}, 550{ }^{\circ} \mathrm{C}\right)$, globules become irregular structures (Fig. 4f). Fe co-occurs within the Si phase 

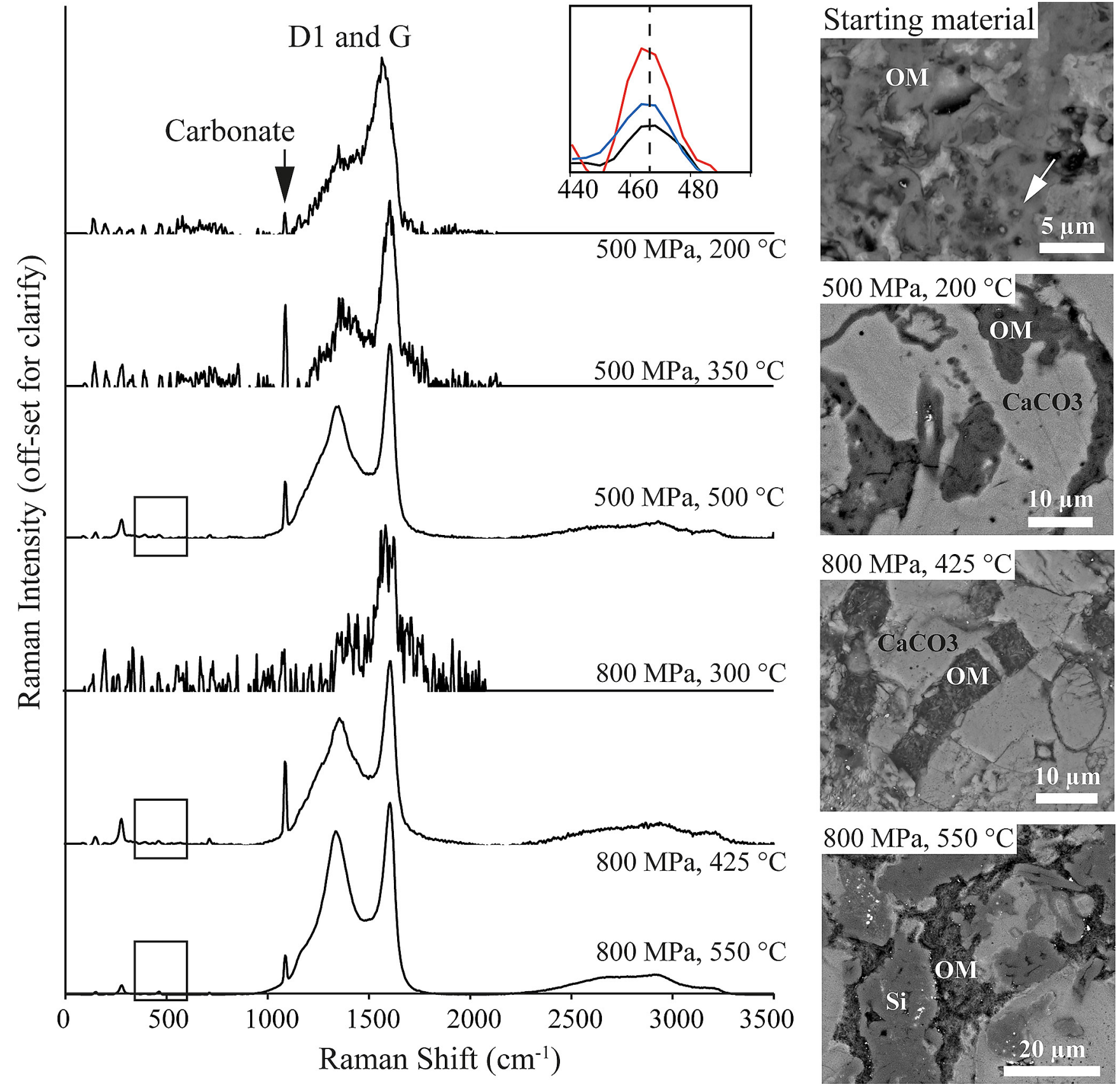

Figure 2 Evolution of D1 $\left(\sim 1360 \mathrm{~cm}^{-1}\right)$ and $\mathrm{G}\left(\sim 1610 \mathrm{~cm}^{-1}\right)$ Raman peaks from experimental samples, and the increasing $467 \mathrm{~cm}^{-1}$ quartz peak at 425,500 , and $550^{\circ} \mathrm{C}$ (box inset); and corresponding SEM images showing the textural evolution of OM mineralisation within the carbonate $\left(\mathrm{CaCO}_{3}\right)$ matrix and siliceous $(\mathrm{Si})$ phases Individual cells in the amorphous organic matrix can be seen in the starting material (arrows). Unprocessed Raman spectra are given in Figure S-3.

for all samples, including in association with the $\mathrm{S}$ globules (Fig. 4h). Despite being a strong Raman scatterer, elemental sulfur was not detected by Raman spectroscopy (Fig. 2).

\section{Discussion}

Within the bounds of a closed system, mm- to micron-scale elemental ( $\mathrm{Si}, \mathrm{S}, \mathrm{Fe}$ ) biosignatures and microbially-derived kerogen maintain their petrographic relationship throughout initial exposure to HPHT (Fig. S-1c). In situ silicification of biomass occurs without petrographic disruption to the captured OM. With increasing PT, the organic-rich amorphous siliceous phase crystallises into $\alpha$-quartz, and the originally porous calcite anneals into a crystalline matrix at $800 \mathrm{MPa}, 550{ }^{\circ} \mathrm{C}$, expelling siliceous $\mathrm{OM}$-bearing material. Extensive fracturing of the carbonate matrix observed at $800 \mathrm{MPa}, 300{ }^{\circ} \mathrm{C}$ may be detrimental to preservation of biosignatures in comparison to an annealed calcite matrix, as the fractures would provide pathways for altering fluids. Disintegration of diatom frustules may be an additional source of Si as PT conditions increase.

Displacement of kerogen during diagenetic coarsening of quartz has been identified as a mechanism to explain petrographic relationships in the microfossil-bearing Gunflint chert (Moreau and Sharp, 2004; Foucher and Westall, 2013). This has implications for the longevity of biosignatures, whereby the quartz fraction resists weathering or secondary aqueous alteration, protecting captured OM (Toporski et al., 2002). The preservation of $\mathrm{OM}$ within silicious material is consistent with Alleon et al. (2016), who demonstrated the role of silica in limiting thermally-induced molecular degradation of $\mathrm{OM}$ in experimental samples. The transformation of Fe minerals to more stable, crystalline phases has also been shown to be conducive to the preservation of organic components (Ferris 


\section{Starting material}
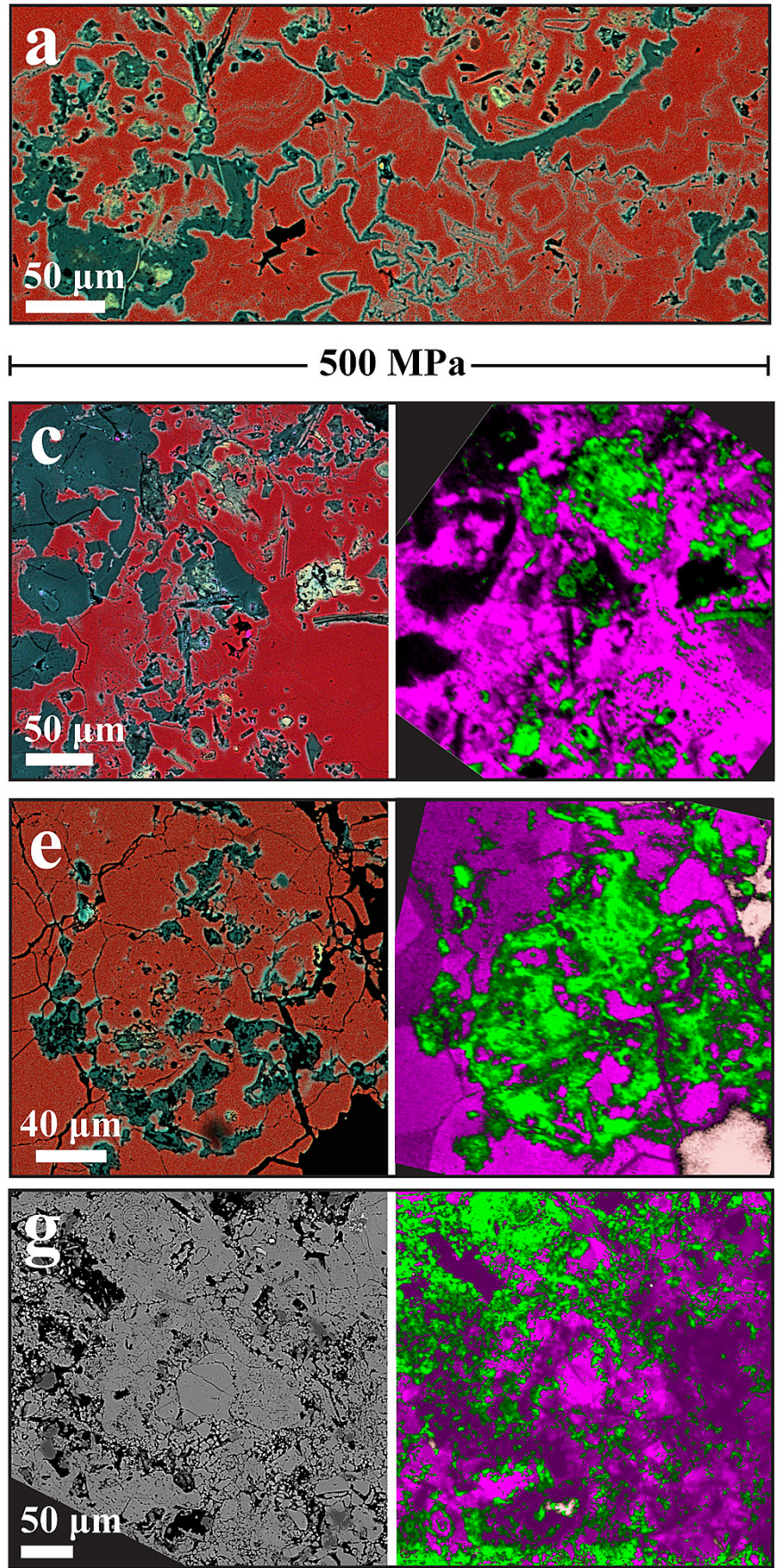
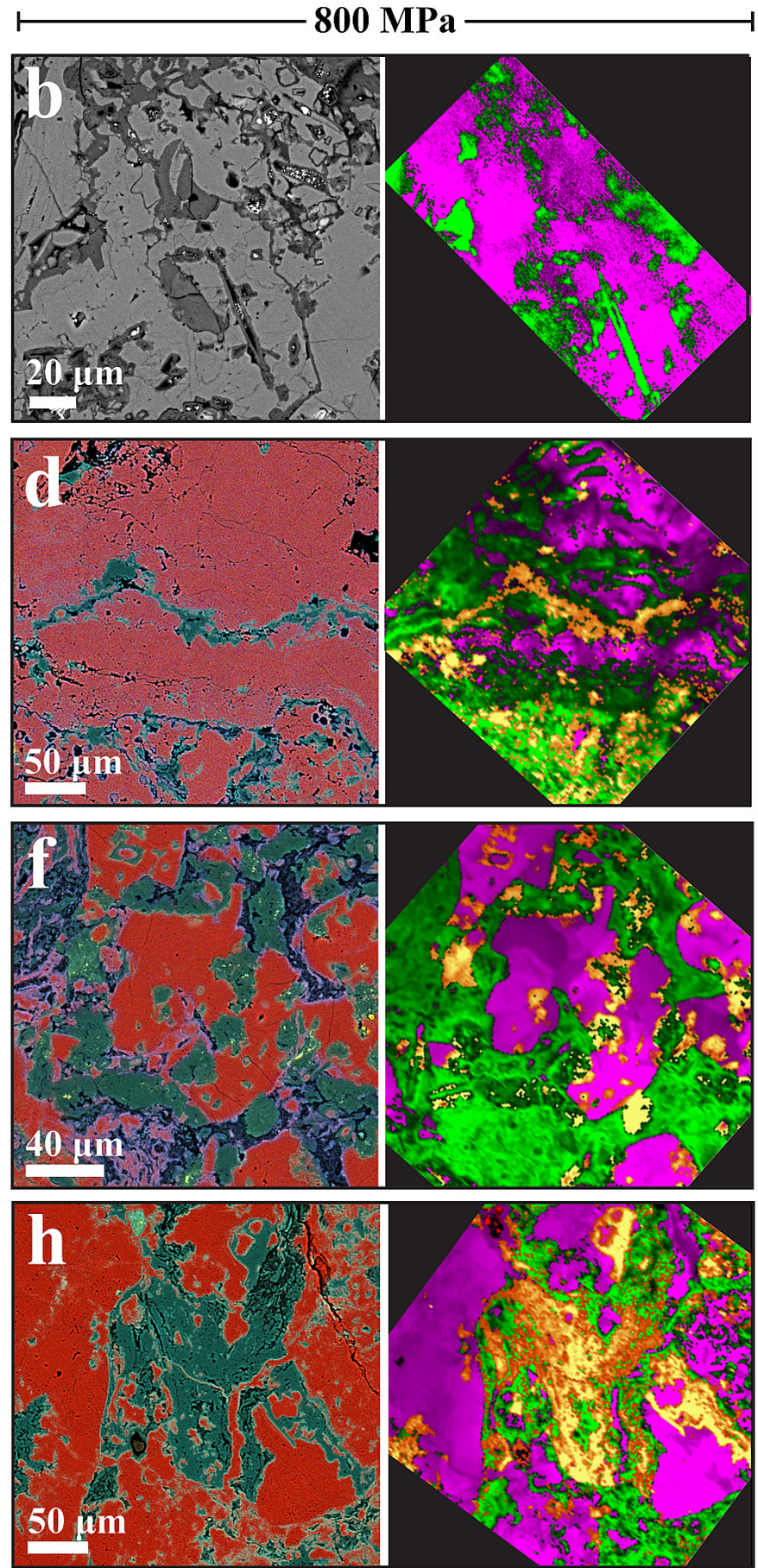

Figure $3 \mathrm{BSE}+\mathrm{EDS}$ elemental maps or plain BSE image (left), where red $=\mathrm{Ca}$ and green $=\mathrm{Si}$, and corresponding Raman maps (right) of the same region, where fuchsia $=$ calcite $\left(1006 \mathrm{~cm}^{-1}\right.$ band), orange/yellow = quartz $\left(465 \mathrm{~cm}^{-1}\right.$ band), green = carbon (combined D1 and G bands), light pink = resin, black = masked fluorescence. (a) Starting material; (b) $800 \mathrm{MPa}, 300^{\circ} \mathrm{C}$; (c) $500 \mathrm{MPa}, 200{ }^{\circ} \mathrm{C}$; (d) 800 $\mathrm{MPa}, 425^{\circ} \mathrm{C}$; (e) $500 \mathrm{MPa}, 350^{\circ} \mathrm{C}$; (f) $800 \mathrm{MPa}, 550^{\circ} \mathrm{C}$; (g) $500 \mathrm{MPa}, 500^{\circ} \mathrm{C}$; (h) $800 \mathrm{MPa}, 550{ }^{\circ} \mathrm{C}$. EDS spectra are provided in Figure S-5.

et al., 1988; Picard et al., 2015a). Finally, the sulfur globules observed in the starting material and experimental samples are consistent in size and shape to intracellular sulfur globules found within filamentous sulfide oxidising bacteria (Dahl and Prange, 2006). Their preservation at the highest HPHT condition holds promise for establishing the biogenicity of similar features in filmentous microfossils (Wacey et al., 2011; Bailey et al., 2013) and distinguishing them from abiotic S microstructures (Cosmidis and Templeton, 2016).

While the OM Raman spectra are relatively close to those observed in the Gunflint and Draken formation (Foucher et al., 2015), such experiments are inheritently limited by their short duration. Even with the addition of P, Raman D1 and G bands of experiment sample $\mathrm{OM}$ are broader than those from metasediments of equivalent metamorphic grade (Beyssac et al., 2002), indicating they are less mature. This limitation was also observed by Li et al. (2014) for experiments at similar temperatures $\left(300{ }^{\circ} \mathrm{C}, 600{ }^{\circ} \mathrm{C}\right)$ in the absence of pressure.

\section{Conclusions}

This study presents an experimental investigation into the first stages of HPHT evolution of microbial biosignatures within a natural siliceous-carbonate matrix. While thermal maturation of $\mathrm{OM}$ is well understood (Vandenbroucke and 

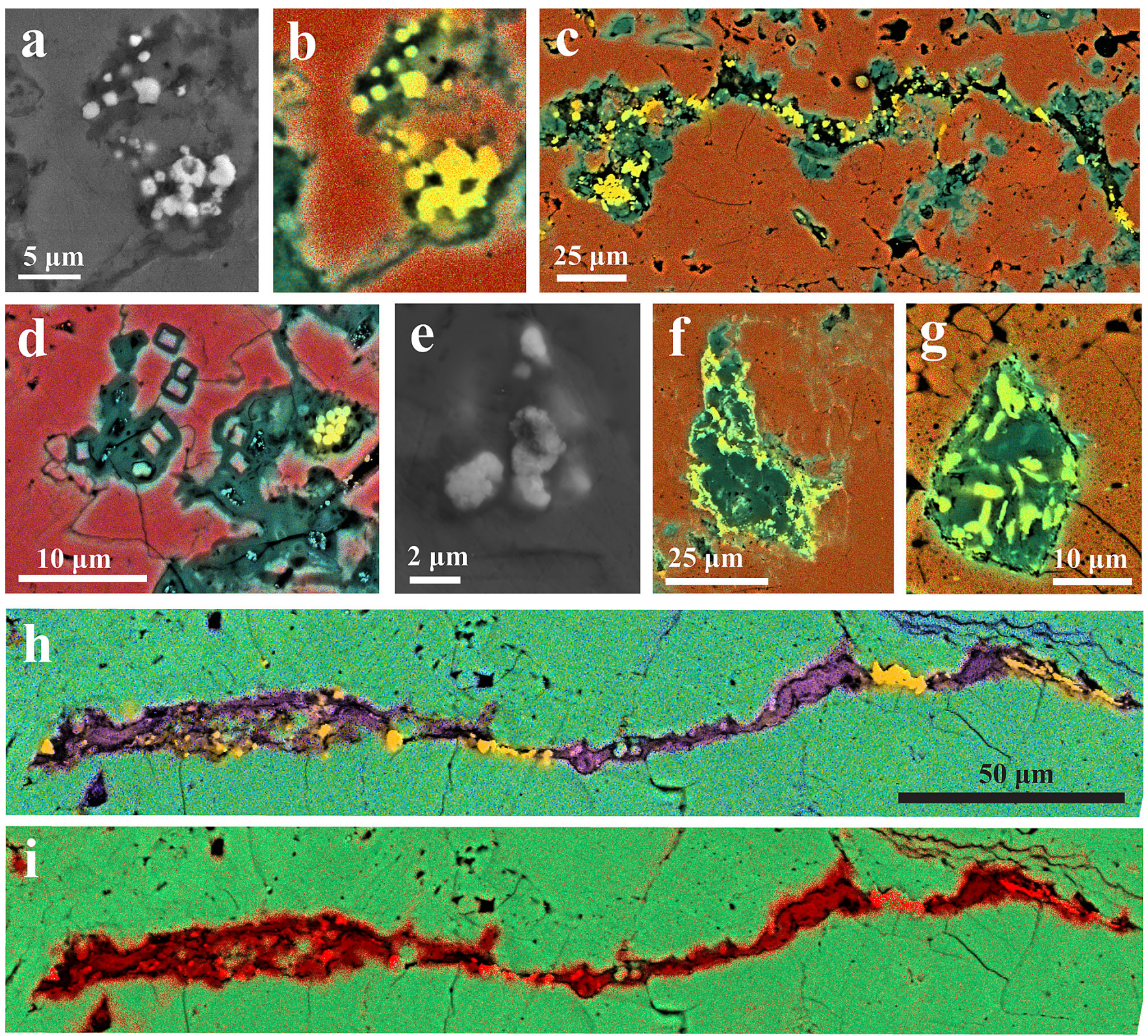

Figure $4(\mathbf{a}-\mathbf{g}) \mathrm{BSE}+\mathrm{EDS}$ elemental maps $(\mathrm{red}=\mathrm{Ca}$, green $=\mathrm{Si}$, yellow $=\mathrm{S})$ and $\mathrm{SEM}$ images of sulfur globules in $(\mathbf{a}$, b) Starting material; (c) $800 \mathrm{MPa}, 425{ }^{\circ} \mathrm{C}$; (d, e) $800 \mathrm{MPa}, 300{ }^{\circ} \mathrm{C}$; (f) $800 \mathrm{MPa}, 550^{\circ} \mathrm{C}$; and (g) $500 \mathrm{MPa}, 500{ }^{\circ} \mathrm{C}$; (h) BSE+EDS elemental map showing the co-location of $\mathrm{Fe}\left(\mathrm{Fe}=\right.$ purple) with $\mathrm{S}\left(\mathrm{S}=\right.$ yellow) within a silica-rich $\left(\mathrm{Si}=\right.$ red) fabric (i) in the $800 \mathrm{MPa}, 425{ }^{\circ} \mathrm{C}$ experiment.

Largeau, 2007), we show that the early effects of temperature and pressure play an important role in the petrographic redistribution and capture of OM due to the transformation of the low temperature silica and carbonate phases. We demonstrate that exposure up to $800 \mathrm{MPa}$ and $550^{\circ} \mathrm{C}$ does not disrupt the petrographic relationship of captured microbial material with its inorganic host phase during the first stages of metamorphism. Future experimental work should address open system effects, including the influence of fluids on the modification of sample components, and longer duration experiments.

\section{Acknowledgements}

This work was funded by a Royal Society of Edinburgh Research Fellowship. FF and FW acknowledge funding from the CNRS and CNES.

Editor: Karim Benzerara

\section{Additional Information}

Supplementary Information accompanies this letter at http:// www.geochemicalperspectivesletters.org/article2002.

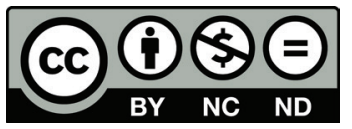

This work is distributed under the Creative Commons Attribution Non-Commercial No-Derivatives 4.0 License, which permits unrestricted distribution provided the original author and source are credited. The material may not be adapted (remixed, transformed or built upon) or used for commercial purposes without written permission from the author. Additional information is available at http://www.geochemicalperspectivesletters.org/ copyright-and-permissions.

Cite this letter as: Cousins, C., Mikhail, S., Foucher, F., Steele, A., Westall, F. (2020) Metamorphic evolution of carbonate-hosted microbial biosignatures. Geochem. Persp. Let. 12, 40-45. 


\section{References}

Alleon, J., Bernard, S., Le Guillou, C., Daval, D., Skouri-Panet, F. Pont, S., Delbes, L., Robert, F. (2016) Early entombment within silica minimizes the molecular degradation of microorganisms during advanced diagenesis. Chemical Geology 437, 98-108.

Alleon, J., Bernard, S., Le Guillou, C., Daval, D., Skouri-Panet, F., KugA, M., RoberT, F. (2017) Organic molecular heterogeneities can withstand diagenesis. Scientific Reports 7, 1508.

Bailey, J.V., Corsetti, F.A., Greene, S.E., Crosby, C.H., Liu, P., ORPHAN, V.J. (2013) Filamentous sulfur bacteria preserved in modern and ancient phosphatic sediments: implications for the role of oxygen and bacteria in phosphogenesis. Geobiology 11, 397-405.

Banks, D., Sletten, R.S., Haldorsen, S., Dale, B., Heim, M., Swensen, B. (1998) The Thermal Springs of Bockfjord, Svalbard: Occurrence and Major Ion Hydrochemistry. Geothermics 27, 445-467.

Bernard, S., Benzerara, K., Beyssac, O., Mgnguy, N., Guyot, F., BROWN JR., G.E., GoFFE, B. (2007) Exceptional preservation of fossi plant spores in high-pressure metamorphic rocks. Earth and Planetary Science Letters 262, 257-272

Bernard, S., Benzerara, K., Beyssac, O., Brown, G.E. (2010) Multiscale characterization of pyritized plant tissues in blueschist facies metamorphic rocks. Geochimica Cosmochimica Acta 74, 5054-5068.

Beyssac, O., Goffé, B, Chopin, C., Rouzaud, J.N. (2002) Raman spectra of carbonaceous material in metasediments: a new geothermometer. Journal of Metamorphic et Geology 20, 859-871.

Brasier, M.D., Green, O.R., Lindsay, J.F., McLoughlin, N., Steele, A., STOAKES, C. (2005) Critical testing of Earth's oldest putative fossil assemblage from the $\sim 3.5 \mathrm{Ga}$ Apex chert, Chinaman Creek, Western Australia. Precambrian Research 140, 55-102.

Cosmidis, J., Templeton, A.S. (2016) Self-assembly of biomorphic carbon/ sulfur microstructures in sulfidic environments. Nature Communications 7, 12812 .

DAHL, C., PRANGE, A. (2006) Bacterial Sulfur Globules: Occurrence, Structure and Metabolism. In: Shively J.M. (Eds) Inclusions in Prokaryotes. Springer, Berlin, Heidelberg, 21-51

Djokic, T., Van Kranendonk, M., Campbell, K.A., Walter, M.R., WARD, C.R. (2017) Earliest signs of life on land preserved in ca. 3.5 Ga hot spring deposits. Nature Communications 8, 15263, doi: 10.1038/ ncomms15263

FERRIS, F.G., FYFE, W.S., BEVERIDGE, T.J. (1988) Metallic ion binding by Bacillus subtilis: implications for the fossilization of microorganisms. Geology 16, 153-157.

FouCheR, F., WeSTALL, F. (2013) Raman Imaging of Metastable Opal in Carbonaceous Microfossils of the 700-800 Ma Old Draken Formation Astrobiology 13, 57-67.

Foucher, F., AMmar, M.R., WeStalL, F. (2015) Revealing the biotic origin of silicified Precambrian carbonaceous microstructures using Raman spectroscopic mapping, a potential method for the detection of microfossils on Mars. Journal of Raman Spectroscopy 46, 873-879.

Gaboyer, F., Milbeau, C.L., Bohmeier, M., Schwendner, P., Vannier, P., Beblo-Vranesevic, K., Rabbow, E., Foucher, F., Gautret, P., Guégan, R., Richard, A., Sauldubois, A., Richmann, P. Perras, A.K., Moissl-Eichinger, C., Cockell, C.S., RetTBerg, P., Marteinsson, V., Monaghan, E., Ehrenfreund, P., Garcia-Descalzo, L., Gomez, F., Malki, M., Amils, R., Cabezas, P., Walter, N., Westall, F. (2017) Mineralization and Preservation of an extremotolerant Bacterium Isolated from an Early Mars Analog Environment. Scientific Reports 7, 14

Galvez, M.W., Beyssac, O., Benzerra, K., Bernard, S., Menguy, N., Cox, C.S., Martinez, I., Johnston, M.R., BRown JR, G.E. (2012) Morphological preservation of carbonaceous plant fossils in blueschist metamorphic rocks from New Zealand. Geobiology 10, 118-129.

Li, J., Benzerara, K., Bernard, S., BeyssaC, O. (2013a) The link between biomineralization and fossilization of bacteria: Insights from field and experimental studies. Chemical Geology 359, 49-69.

LI, Y.L., Konhauser, K.O., KappleR, A., HaO X.L. (2013b) Experimental low-grade alteration of biogenic magnetite indicates microbial involvement in generation of banded iron formations. Earth and Planetary Science Letters, 361, 229-237.

Li, J., Bernard, S., Benzerara, K., Beyssac, O., Allard, T., Cosmidis, J., MoussoU, J. (2014) Impact of biomineralization on the preservation of microorganisms during fossilization: An experimental perspective. Earth and Planetary Science Letters 400, 113-122.
Moreau, J.W., SHare, T.G. (2004) A Transmission Electron Microscopy Study of Silica and Kerogen Biosignatures in 1.9 Ga Gunflint Microfossils. Astrobiology 4, 196-210.

Miot, J., Bernard, S., Bourreau, M., Guyot, F., Kish, A. (2017) Experimental maturation of Archaea encrusted by Fe-phosphates. Scientific Reports 7, 16984

Orange, F., Disnar, J.R., Gautret, P., Westall, F., Bienvenu, N., LotTIER, N., PrIEUR, D. (2012) Preservation and evolution of organic matter during experimental fossilisation of the hyperthermophilic archaea Methanocaldococcus jannaschii. Origins of Life and Evolution of Biospheres 42, 587-609.

Orange, F., Dupont, S., Goff, O.L., Bienvenu, N., Disnar, J.R., Westall, F., Le Romancer, M., (2014) Experimental fossilization of the thermophilic Gram-positive Bacterium Geobacillus SP7A: a long duration preservation study. Geomicrobiology Journal 31, 578-589.

Papineau, D., DeGregorio, B., Sagar, J., Thorogate, R., Wang, J., Nittler, L., Kilcoyne, D.A., Marbach, H., Drost, M. ThORNTON, G. (2019) Fossil biomass preserved as graphitic carbon in a late Paleoproterozoic banded iron formation metamorphosed at more than $550^{\circ} \mathrm{C}$. Journal of the Geological Society of London 176, 651-668.

Picard, A., Kappler, A., Schmid, G., Quaroni, L., Obst, M. (2015a) Experimental diagenesis of organo-mineral structures formed by microaerophilic Fe(II)-oxidizing bacteria. Nature Communications 6, 6277 (2015), doi: 10.1038/ncomms7277.

Picard, A., Obst, M., Schmid, G., Zeitvogel, F., Kappler, A. (2015b) Limited influence of $\mathrm{Si}$ on the preservation of Fe mineral-encrusted microbial cells during experimental diagenesis Geobiology 14, 276-292.

Pimenta, M.A., Dresselhaus, G., Dresselhaus, M.S., Cancado, L.G., Jorio, A., SAITO, R. (2007) Studying disorder in graphite-based systems by Raman spectroscopy. Physical Chemistry Chemical Physics 9, 1276-1291.

Schiffbauer, J. D., Wallace, A.F., Hunter, J.L., Kowalewski, M., BODNAR, R.J., XIAO, S. (2012) Thermally induced structural and chemical alteration of organic walled microfossils: an experimental approach to understanding fossil preservation in metasediments. Geobiology 10, 402-423.

Starke, V., Kirshtein, J., Fogel, M.L., Steele, A. (2013) Microbial community composition and endolith colonization at an Arctic thermal spring are driven by calcite precipitation. Environmental Microbiology Reports 5, 648-659, doi: 10.1111/1758-2229.12063.

Toporski, J.K., Steele, A., Westall, F., Thomas-Keprta, K.L., McKay, D.S. (2002) The simulated silicification of bacteria - new clues to the modes and timing of bacterial preservation and implications for the search for extraterrestrial microfossils. Astrobiology 2, 1-26.

Wacey, D., Kilburn, M.R., SAunders, M., ClifF, J., Brasier, M.D. (2011) Microfossils of sulphur-metabolizing cells in 3.4-billion-year-old rocks of Western Australia. Nature Geoscience 4, 698-702.

Westall, F., Boni, L., Guerzoni, E. (1995) The experimental silicification of microorganisms. Palaeontology 38, 495-528.

WestALL, F. (2008) Morphological Biosignatures in Early Terrestrial and Extraterrestrial Materials. Space Science Reviews 135, 95-114.

Westall, F., Campbell, K.A., Bréhéret, J.G., Foucher, F., Gautret, P., Hubert, A., Sorieul, S., Grassineau, N., Guido, D.M. (2015) Archean $(3.33 \mathrm{Ga})$ microbe-sediment systems were diverse and flourished in a hydrothermal context. Geology 43, 615-618. 